\title{
Article \\ Mechanisms of MEHP Inhibitory Action and Analysis of Potential Replacement Plasticizers on Leydig Cell Steroidogenesis
}

\author{
Annick N. Enangue Njembele ${ }^{1,+}$ and Jacques J. Tremblay ${ }^{1,2, *}$ (D) \\ 1 Reproduction, Mother and Child Health, Room T3-67, Centre de Recherche du CHU de Québec-Université \\ Laval CHUL 2705 Laurier Blvd., Québec City, QC G1V 4G2, Canada; enangue7@yahoo.fr \\ 2 Centre for Research in Reproduction, Development and Intergenerational Health, Department of Obstetrics, \\ Gynecology, and Reproduction, Faculty of Medicine, Université Laval, Québec City, QC G1V 0A6, Canada \\ * Correspondence: Jacques-J.Tremblay@crchudequebec.ulaval.ca; Tel.: +1-418-525-4444 (ext. 46254) \\ + Present address: Station of Research in Marine Ecosystems of Kribi, Institute of Agricultural Research for \\ development (IRAD), P.O. Box 219, Kribi, Cameroon.
}

check for

updates

Citation: Enangue Njembele, A.N.; Tremblay, J.J. Mechanisms of MEHP Inhibitory Action and Analysis of Potential Replacement Plasticizers on Leydig Cell Steroidogenesis. Int. J. Mol. Sci. 2021, 22, 11456. https:// doi.org/10.3390/ijms222111456

Academic Editors: Thierry Charlier, Devaleena S. Pradhan and Cathy Vaillancourt

Received: 24 September 2021

Accepted: 22 October 2021

Published: 24 October 2021

Publisher's Note: MDPI stays neutral with regard to jurisdictional claims in published maps and institutional affiliations.

Copyright: (c) 2021 by the authors. Licensee MDPI, Basel, Switzerland. This article is an open access article distributed under the terms and conditions of the Creative Commons Attribution (CC BY) license (https:// creativecommons.org/licenses/by/ $4.0 /)$.

\begin{abstract}
Steroid production in Leydig cells is stimulated mainly by the pituitary luteinizing hormone which leads to increased expression of genes involved in steroidogenesis, including the gene encoding the steroidogenic acute regulatory (STAR) protein. Mono(2-ethylhexyl)phthalate (MEHP), the active metabolite of the widely used plasticizer DEHP, is known to disrupt Leydig steroidogenesis but its mechanisms of action remain poorly understood. We found that MEHP caused a significant reduction in hormone-induced steroid hormone production in two Leydig cell lines, MA-10 and MLTC-1. Consistent with disrupted cholesterol transport, we found that MEHP represses cAMP-induced Star promoter activity. MEHP responsiveness was mapped to the proximal Star promoter, which contains multiple binding sites for several transcription factors. In addition to STAR, we found that MEHP also reduced the levels of ferredoxin reductase, a protein essential for electron transport during steroidogenesis. Finally, we tested new plasticizers as alternatives to phthalates. Two plasticizers, dioctyl succinate and 1,6-hexanediol dibenzoate, had no significant effect on hormone-induced steroidogenesis. Our current findings reveal that MEHP represses steroidogenesis by affecting cholesterol transport and its conversion into pregnenolone. We also found that two novel molecules with desirable plasticizer properties have no impact on Leydig cell steroidogenesis and could be suitable phthalate replacements.
\end{abstract}

Keywords: testis; Leydig cells; steroidogenesis; Star; environmental toxicology; endocrine disrupters; phthalates; DEHP; green plasticizers

\section{Introduction}

Phthalates or phthalate esters are a family of lipophilic chemicals that are primarily used as plasticizers and additives to improve flexibility and durability of a product. Phthalates are widely used in the manufacture of polyvinyl chloride (PVC) and consequently can be found in several consumer and industrial products [1,2] such as medical devices (blood/fluid bags, intravenous tubing), food wrapping and packaging [3,4], cosmetics [5] (shampoo, perfume) [6], toys [7,8], paint and finishes, and upholstery [9]. It is known that phthalates are not covalently bound to their matrix in PVC and thus are released into the environment (reviewed in [10]). Consequently, phthalates contaminate food and water chains and can be found in human and animal fluids (reviewed in $[11,12])$. Di(2ethylhexyl)phthalate (DEHP) is the most abundant phthalate. Approximately 95\% of DEHP produced is used as a plasticizer in PVC [13]. In 2004, the worldwide production of DEHP was estimated to be about 2 million metric tons (4.4 billion pounds) (reviewed in [14-16]). Despite the controversy surrounding its effects, DEHP consumption continued to rise to an estimated 3.07 million metric tons (6.754 billion pounds) in 2017 (reviewed in [12]). 
DEHP is absorbed in the body via three main routes: ingestion, inhalation, and dermal absorption (reviewed in [17]). Although variable, daily DEHP exposure is estimated in humans at $8 \mu \mathrm{g} / \mathrm{kg}$ of body weight in adults and $25 \mu \mathrm{g} / \mathrm{kg}$ of body weight in children (reviewed in [1,18-22]). Inside the body, phthalates-including DEHP-are metabolized by hydrolysis and conjugation and then eliminated in urine (reviewed in [12]). During hydrolysis, DEHP is mainly metabolized like other phthalates by intestinal esterase and lipase into two main components: monoethylhexyl phthalate (MEHP) and ethylhexanol [22,23]. Following oxidation and hydroxylation, MEHP, the most abundant metabolite of DEHP, is further metabolized into other secondary metabolites. Some of these secondary metabolites are eliminated directly in urine, while others are conjugated, mostly by glucuronidation, then eliminated in urine and feces [23]. Some of the conjugated metabolites of DEHP remain in blood plasma [24].

Several studies performed in rodents have revealed that exposure to DEHP/MEHP causes reproductive abnormalities in adult males and in fetuses exposed in utero or during lactation ([25-28], reviewed in [29]). In rats, in utero exposure to DEHP causes reduced anogenital distance, cryptorchidism, hypospadias, multinucleated germ cells, increased aggregation of Leydig cells, and decreased testosterone production in male offspring [30-35]. In humans, exposure of human fetal testis explants in culture to DEHP results in decreased testosterone production [36] and is associated with reduced Leydig cell function [37,38]. In all studies, DEHP toxicity was found to be conferred mainly by MEHP $[20,39,40]$. Exposure to MEHP was found to decrease testosterone production by targeting Leydig cells [35,40-42].

Steroid synthesis in Leydig cells involves a well-characterized biosynthetic pathway requiring the sequential action of multiple enzymes (reviewed in [43]). The initial and rate limiting step in steroidogenesis, stimulated by the steroidogenic acute regulatory protein (STAR), involves cholesterol transport from the outer to the inner mitochondrial membrane where it can be converted to pregnenolone by the enzyme P450 side-chain cleavage (P450SCC, CYP11A1). Pregnenolone is then exported from the mitochondria and imported into the endoplasmic reticulum where it is transformed into testosterone through the sequential action of P450 17 $\alpha$-hydroxylase (CYP17A1), 3 $\beta$-hydroxysteroid dehydrogenase (HSD3B1), and 17 $\beta$-hydroxysteroid dehydrogenase type 3 (HSD17B3). Additional proteins are also required to ensure proper functioning of the various enzymes; these include cytochrome b5 (CYT B5), P450 oxidoreductase (POR), ferredoxin (FDX1), and ferredoxin reductase (FDXR, also known as adrenodoxin reductase, ADXR) (reviewed in [43]).

Leydig cell steroidogenesis is stimulated by the binding of the pituitary luteinizing hormone (LH) to its receptor, leading to a rise in cAMP production and activation of multiple signaling pathways and kinases including PKA, ERK, and CAMKI ([44], reviewed in $[45,46])$. These kinases then phosphorylate transcription factors which upregulate the expression of several genes involved in steroidogenesis (reviewed in $[45,46]$ ), including the Star gene which codes for the STAR protein (reviewed in [47-50]). Several studies performed using animal models, rodent testis in culture, and Leydig cell lines revealed that MEHP negatively affects steroidogenesis by decreasing the expression of several genes involved in androgen production, including the Star gene [40-42,51,52]. The molecular mechanisms of MEHP inhibitory action on Star gene expression remain to be fully elucidated. In addition, growing concerns with respect to environmental and health problems caused by phthalates emphasized the necessity to develop greener plasticizers that would be less likely to leach, more quickly degraded, and less toxic as alternatives to phthalates. Although some replacement plasticizers have been developed and used, data regarding their effects are limited (reviewed in [53]).

In the present work, we used two Leydig cell lines, MA-10 and MLTC-1, to study the mechanisms of MEHP action on Leydig cell steroidogenesis. We provide evidence that MEHP targets at least two critical steps of steroidogenesis, cholesterol transport, and its conversion into pregnenolone. We also tested the effects of a series of novel plasticizers 
as phthalate replacements and found that two had no significant impact on Leydig cell steroidogenesis.

\section{Results}

\subsection{MEHP Represses Steroidogenesis by Affecting Star Gene Transcription}

MEHP has been reported to decrease Star mRNA and protein levels in MA-10 Leydig cells and in primary Leydig cell cultures $[41,51,52,54,55]$. However, it is not known whether this is caused by a decrease in Star transcription. To test this possibility, a -980 bp mouse Star promoter fused to luciferase was transiently transfected in MA-10 Leydig cells which were exposed to increasing doses of $\operatorname{MEHP}(0.5,10,30,75$, and $150 \mu \mathrm{M})$. As shown in Figure 1A, MEHP had no effect on basal Star promoter activity. Treatment with 8Br-cAMP led to a 13-fold stimulation of the Star promoter as expected (Figure 1A). Co-treatment with 0.5 and $10 \mu \mathrm{M}$ MEHP did not impact cAMP-mediated stimulation. However, higher MEHP doses (30, 75, and $150 \mu \mathrm{M})$ reduced cAMP-induced Star promoter activity by about $50 \%$ (Figure 1A).

To locate the MEHP-responsive region, a series of $5^{\prime}$ progressive deletion constructs of the mouse Star promoter were transfected in MA-10 Leydig cells treated with DMSO (vehicle) or $150 \mu \mathrm{M}$ of MEHP. As shown in Figure 1B, the cAMP response was still decreased by MEHP up to $-95 \mathrm{bp}$. The cAMP induction of a $-70 \mathrm{bp}$ Star reporter was no longer repressed by MEHP (Figure 1B). Thus the MEHP-responsive region seems to be located within the proximal Star promoter, a region that contains binding sites for several important transcription factors including SF1, NUR77, C/EBP $\beta$, GATA4, and AP1 (reviewed in [56]). We therefore assessed whether MEHP decreased the levels of some of these transcription factors. As shown in Figure 1C, protein levels of both SF1 and C/EBP $\beta$ were not affected by MEHP.

We next performed similar experiments in MLTC-1 Leydig cells to confirm that the effects of MEHP were not unique to the MA-10 Leydig cell line. Another advantage of the MLTC- 1 cells is that they produce testosterone. We therefore tested the effect of $100 \mu \mathrm{M}$ MEHP on progesterone (Figure 2A) and testosterone (Figure 2B) production by MLTC-1 Leydig cells. MEHP did not affect basal progesterone or testosterone production in MLTC-1 cells (Figure 2). Treatment with hCG led to an increase in steroid hormone production which was significantly reduced in the presence of MEHP (Figure 2A,B). MTT assay revealed that this decrease in the presence of MEHP was not caused by a reduction in cell viability or mitochondrial integrity (Figure 2C). Finally, MEHP also repressed cAMPinduced Star promoter activity in MLTC-1 cells (Figure 2D). A small but significant increase in Star basal promoter activity was observed at $150 \mu \mathrm{M}$ MEHP. Thus, MEHP represses steroidogenesis by affecting cAMP/hormone-induced Star transcription in two Leydig cell lines.

A

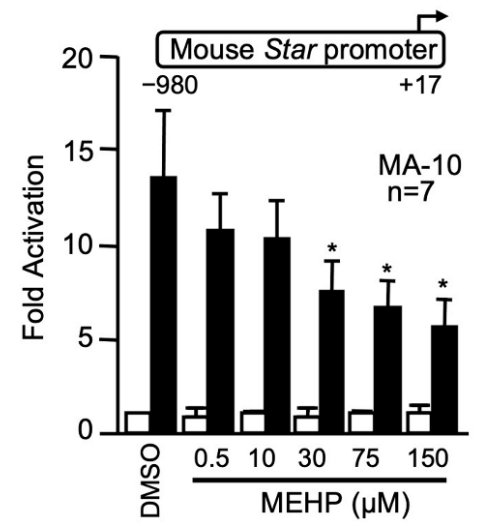

Figure 1. Cont. 


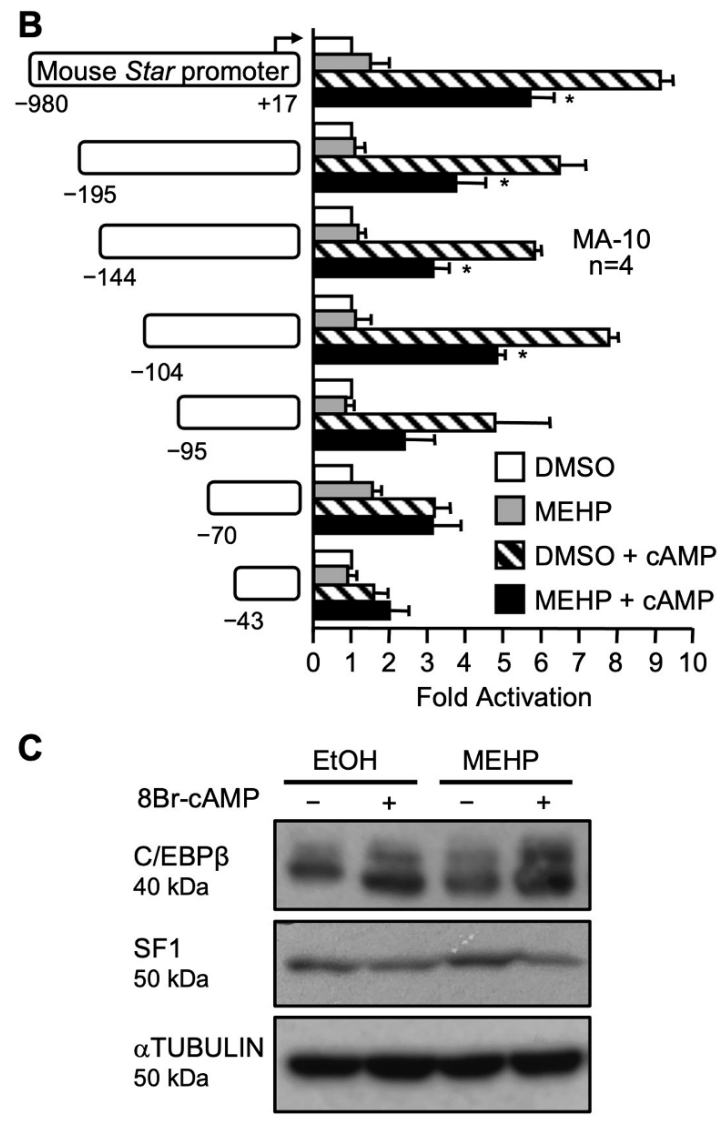

Figure 1. MEHP targets the proximal Star promoter in MA-10 Leydig cells. (A) MA-10 were transfected with a $-980 \mathrm{bp}$ mouse Star reporter and treated for $24 \mathrm{~h}$ with either dimethylsulfoxide (DMSO) or increasing concentrations of MEHP in the presence (black bars) or absence (white bars) of $0.1 \mathrm{mM} 8 \mathrm{Br}$-cAMP. Results are shown as fold activation over control. Values are the mean of seven individual experiments performed in triplicate $( \pm \mathrm{SEM})$. (B) MEHP targets the proximal Star promoter. A series of $5^{\prime}$ progressive deletions of the mouse Star promoter were transfected in MA-10 Leydig cells and treated with either dimethylsulfoxide (DMSO, white bars) or $150 \mu \mathrm{M}$ MEHP (gray bars) in the presence (hatched and black bars) or absence (white and gray bars) of $0.1 \mathrm{mM}$ 8Br-cAMP. Results are shown as fold activation over control. Values are the mean of four individual experiments performed in triplicate ( \pm SEM). (C) MA-10 Leydig cells were treated with either dimethylsulfoxide (DMSO) or $100 \mu \mathrm{M}$ MEHP with or without $0.1 \mathrm{mM} 8 \mathrm{Br}-\mathrm{cAMP}$ and whole cell extracts were prepared for immunodetection of $C / E B P \beta$ and SF1. $\alpha$ TUBULIN was used as a loading control. All experiments were repeated three times and produced similar results. ${ }^{*}: p \leq 0.05$.

A

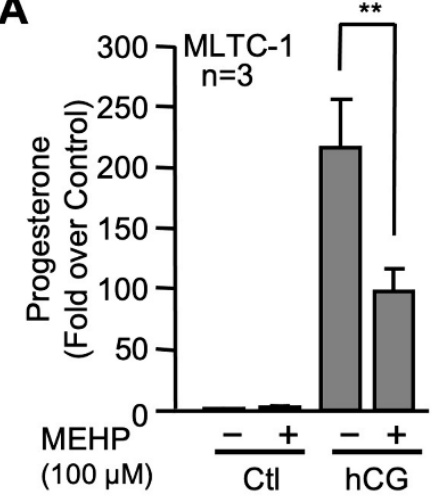

B

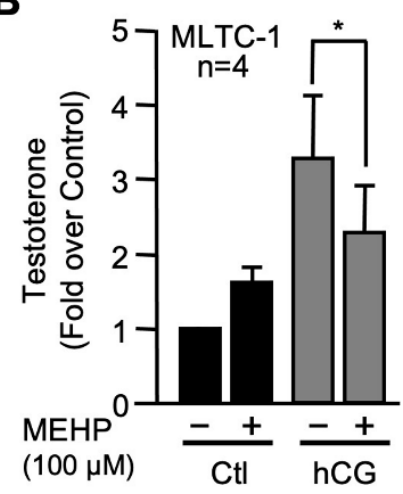

Figure 2. Cont. 
C

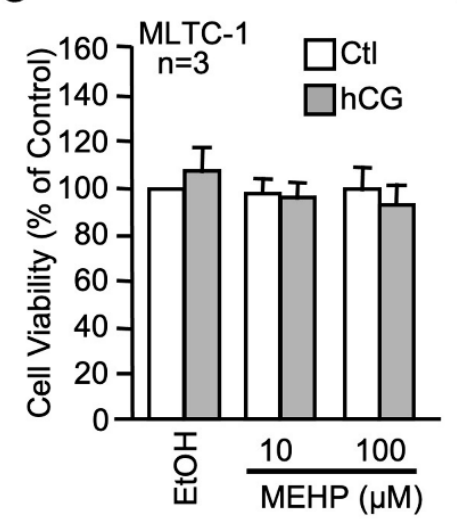

D

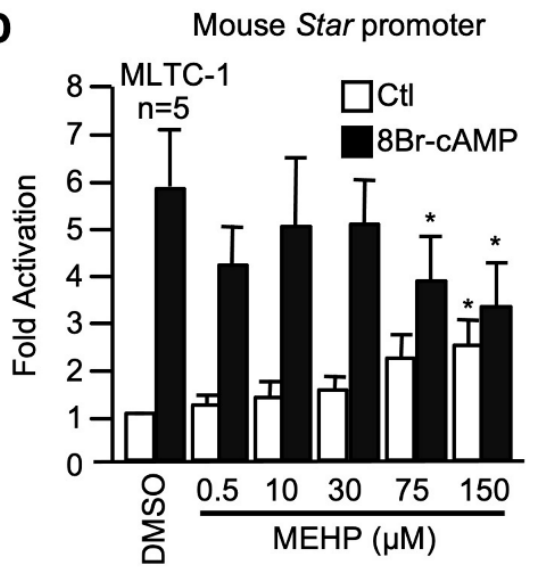

Figure 2. MEHP represses steroidogenesis in MLTC-1 Leydig cells. Progesterone (A) and testosterone (B) production were measured from MLTC-1 Leydig cells exposed to EtOH (-) or $100 \mu \mathrm{M} \mathrm{MEHP}$ (+) in the presence (gray bars) or absence (black bars) of $20 \mathrm{ng} / \mathrm{mL}$ of hCG. Values are the mean of 3 (progesterone) or 4 (testosterone) experiments each performed in duplicate ( \pm SEM). (C) MEHP does not affect MLTC-1 Leydig cell viability. MLTC-1 Leydig cells were treated with either EtOH or two concentrations of MEHP $(10,100 \mu \mathrm{M})$ for $24 \mathrm{~h}$ in presence (gray bars) or absence (white bars) of $20 \mathrm{ng} / \mathrm{mL}$ of hCG. Cell viability was determined by performing MTT assays. Values are the mean of three individual experiments each performed in triplicate ( \pm SEM). (D) MEHP represses cAMP-induced Star promoter activity in MLTC-1 Leydig cells. MLTC-1 cells were transfected with a $-980 \mathrm{bp}$ mouse Star reporter and treated for $24 \mathrm{~h}$ with either dimethylsulfoxide (DMSO) or increasing concentrations of MEHP in the presence (black bars) or absence (white bars) of $0.1 \mathrm{mM} 8 \mathrm{Br}$-cAMP. Results are shown as fold activation over control. Values are the mean of five individual experiments performed in triplicate $( \pm \mathrm{SEM}){ }^{*}: p \leq 0.05,{ }^{* *}: p \leq 0.01$.

\subsection{MEHP Affects FDXR Expression}

Since hormone-induced progesterone production was affected in the presence of MEHP, we tested whether MEHP could also affect the expression of proteins involved in cholesterol conversion into pregnenolone. Expression of two key proteins, CYP11A1 (P450 side-chain cleavage) and FDXR (ferredoxin reductase), was analyzed by Western blotting. While CYP11A1 levels were unaffected (Figure 3A), FDXR protein levels were decreased in the presence of MEHP (Figure 3B). Thus, MEHP reduces the levels FDXR, a protein involved in cholesterol conversion, in addition to STAR, which is involved in cholesterol transport in the mitochondria.

A

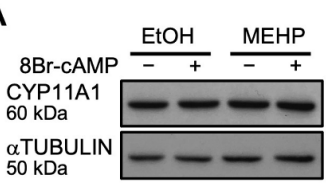

$50 \mathrm{kDa}$
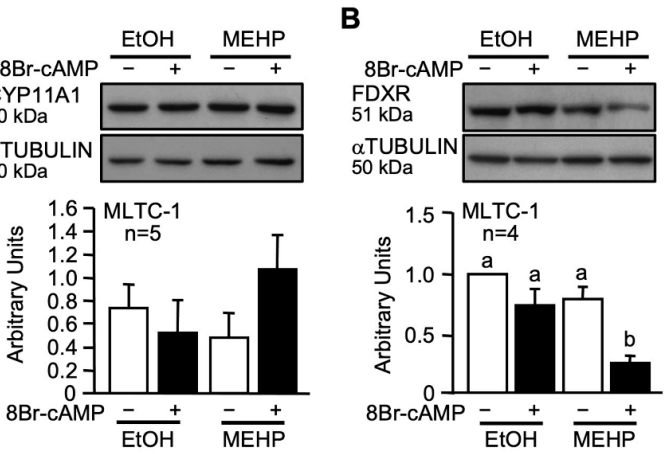

Figure 3. MEHP affects FDXR protein levels. MLTC-1 cells were treated for $24 \mathrm{~h}$ with either EtOH or $100 \mu \mathrm{M}$ MEHP in the absence or presence of $0.1 \mathrm{mM} 8 \mathrm{Br}-\mathrm{cAMP}$. Whole cell extracts were prepared and used for immunodetection of CYP11A1 (A) and FDXR (B). $\alpha$ TUBULIN was used as a loading control. All experiments were repeated four or five times as indicated and produced similar results. Values are the mean of densitometry of all individual experiments ( \pm SEM). A different letter indicates a statistically significant difference $(p \leq 0.05)$. 


\subsection{Effects of Novel Green Plasticizers on Leydig Cell Function}

Since phthalates are detrimental to Leydig cell gene expression and function, we tested the effects of novel biodegradable molecules that also have desirable plasticizing properties [57-60] on Leydig cell steroidogenesis as potential alternatives to phthalates. Four classes of novel plasticizers were tested: n-alkyl dibenzoate (Figure 4), n-alkyl diester succinate (Figure 5), n-alkyl diester maleate (Figure 6), and n-alkyl diester fumarate (Figure 7). Comparisons were also performed with two commercially available plasticizing molecules: Hexamoll-DINCH and diethylhexyl adipate (DEHA) (Figure 8).

A

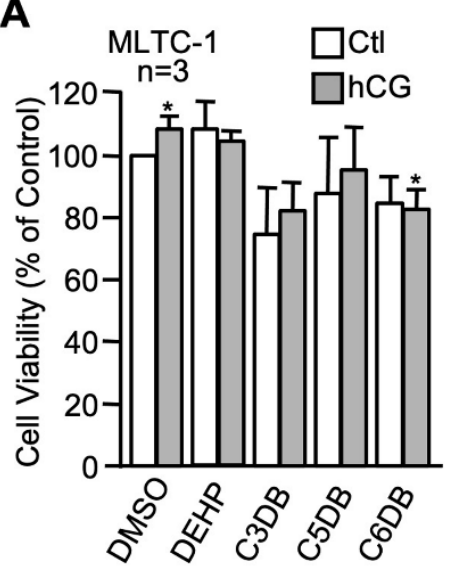

C Mouse Star promoter

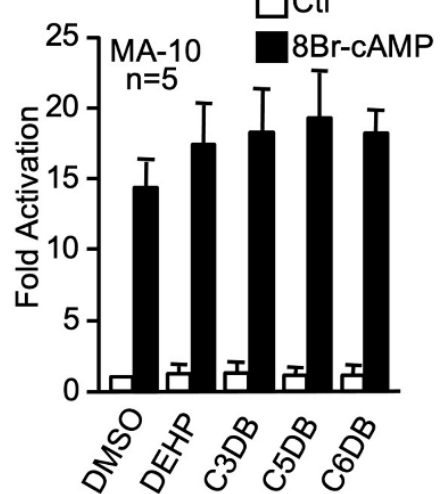

B

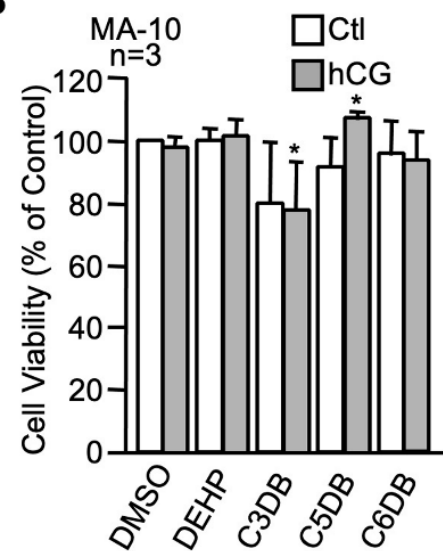

D

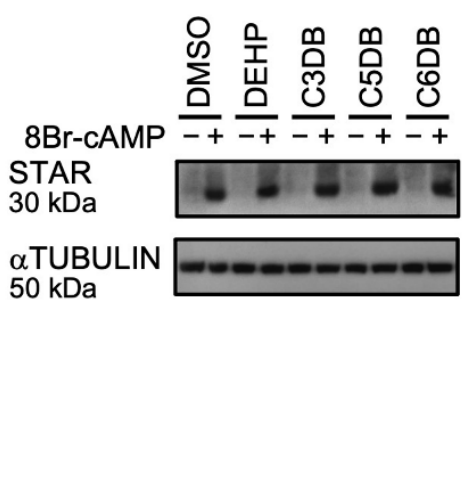

Figure 4. Effects of n-alkyl dibenzoate plasticizers on MA-10 and MLTC-1 Leydig cells. MA-10 (A) and MLTC-1 (B) cells were treated for $24 \mathrm{~h}$ with either dimethylsulfoxide (DMSO) or $100 \mu \mathrm{M}$ of n-alkyl dibenzoate plasticizers as indicated in the presence (gray bars) or absence (white bars) of $20 \mathrm{ng} / \mathrm{mL}$ hCG and cell viability was determined by MTT assays. Values are the mean of three individual experiments each performed in triplicate $( \pm$ SEM). (C) MA-10 Leydig cells were transfected with a $-980 \mathrm{bp}$ mouse Star reporter and treated with $100 \mu \mathrm{M}$ of the different n-alkyl dibenzoate plasticizers as indicated in the absence (white bars) or presence (black bars) of $0.1 \mathrm{mM} 8 \mathrm{Br}$-cAMP. Results are shown as fold activation over control. Values are the mean of five individual experiments performed in triplicate $( \pm$ SEM). (D) STAR protein levels were determined in MA-10 Leydig cells treated with vehicle (DMSO) or the various n-alkyl dibenzoate plasticizers as indicated in the absence $(-)$ or presence $(+)$ of $8 \mathrm{Br}-\mathrm{cAMP}$. $\alpha$ TUBULIN was used as a loading control. All experiments were repeated three times and produced similar results. *: $p \leq 0.05$. 

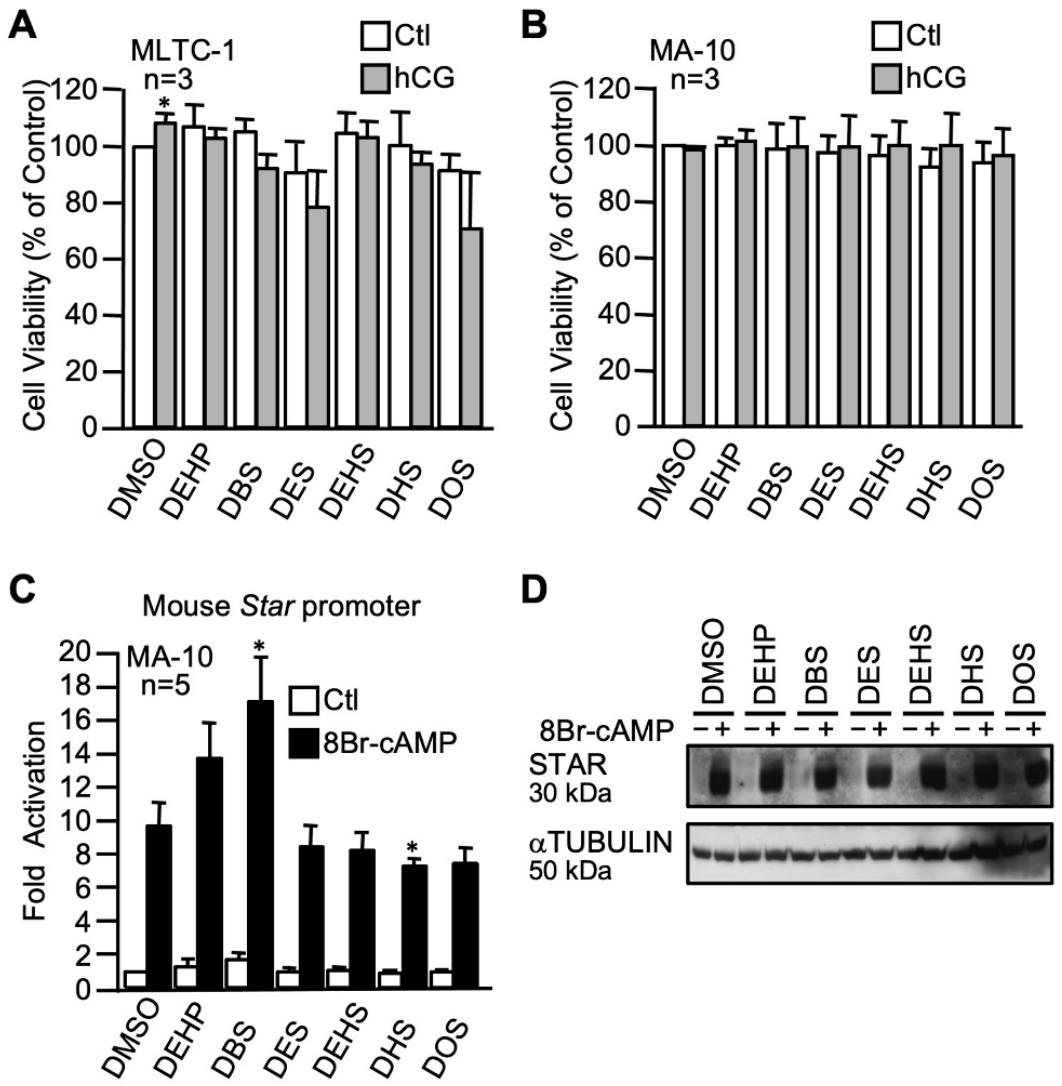

Figure 5. Effects of n-alkyl succinate plasticizers on MA-10 and MLTC-1 Leydig cells. MA-10 (A) and MLTC-1 (B) cells were treated for $24 \mathrm{~h}$ with either dimethylsulfoxide (DMSO) or $100 \mu \mathrm{M}$ of n-alkyl succinate plasticizers as indicated in the presence (gray bars) or absence (white bars) of $0.1 \mathrm{mM}$ hCG and cell viability was determined by MTT assays. Values are the mean of three individual experiments each performed in triplicate $( \pm$ SEM). (C) MA-10 Leydig cells were transfected with a $-980 \mathrm{bp}$ mouse Star reporter and treated with $100 \mu \mathrm{M}$ of the different n-alkyl succinate plasticizers as indicated in the absence (white bars) or presence (black bars) of $0.1 \mathrm{mM} 8 \mathrm{Br}$-cAMP. Results are shown as fold activation over control. Values are the mean of five individual experiments performed in triplicate $( \pm S E M)$. (D) STAR protein levels were determined in MA-10 Leydig cells treated with vehicle (DMSO) or the various n-alkyl succinate plasticizers as indicated in the absence $(-)$ or presence $(+)$ of 8 Br-cAMP. $\alpha$ TUBULIN was used as a loading control. All experiments were repeated three times and produced similar results. ${ }^{*}: p \leq 0.05$.
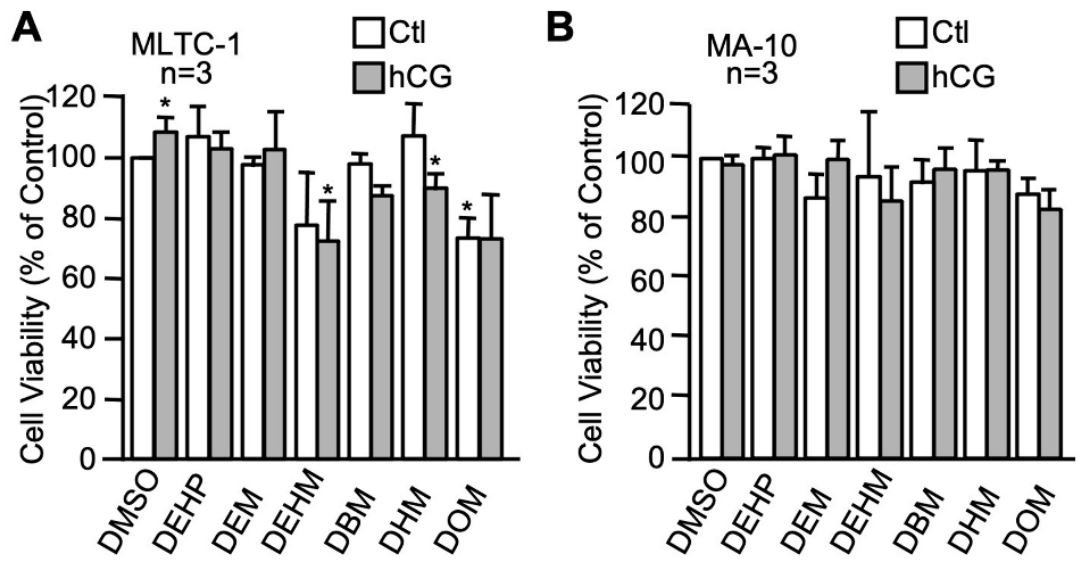

Figure 6. Cont. 


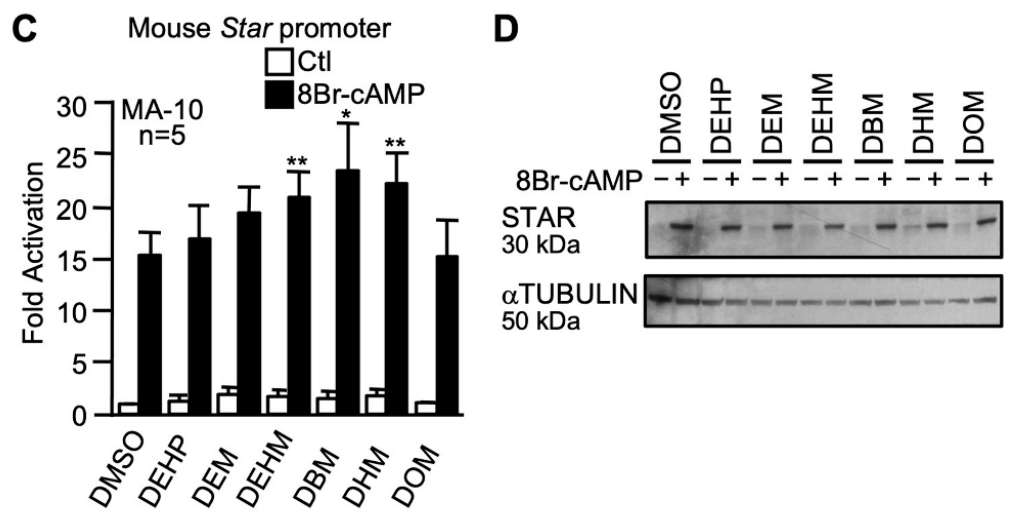

Figure 6. Effects of n-alkyl maleate plasticizers on MA-10 and MLTC-1 Leydig cells. MA-10 (A) and MLTC-1 (B) cells were treated for $24 \mathrm{~h}$ with either dimethylsulfoxide (DMSO) or $100 \mu \mathrm{M}$ of $\mathrm{n}$-alkyl maleate plasticizers as indicated in the presence (gray bars) or absence (white bars) of $20 \mathrm{ng} / \mathrm{mL} \mathrm{hCG}$ and cell viability was determined by MTT assays. Values are the mean of three individual experiments each performed in triplicate $( \pm$ SEM). (C) MA-10 Leydig cells were transfected with a -980 bp mouse Star reporter and treated with $100 \mu \mathrm{M}$ of the different n-alkyl maleate plasticizers as indicated in the absence (white bars) or presence (black bars) of $0.1 \mathrm{mM} 8 \mathrm{Br}-\mathrm{cAMP}$. Results are shown as fold activation over control. Values are the mean of five individual experiments performed in triplicate ( \pm SEM). (D) STAR protein levels were determined in MA-10 Leydig cells treated with vehicle (DMSO) or the various n-alkyl maleate plasticizers as indicated in the absence $(-)$ or presence $(+)$ of $8 \mathrm{Br}$-cAMP. $\alpha$ TUBULIN was used as a loading control. All experiments were repeated three times and produced similar results. *: $p \leq 0.05,{ }^{* *}: p \leq 0.01$ when compared to control (DMSO + cAMP).
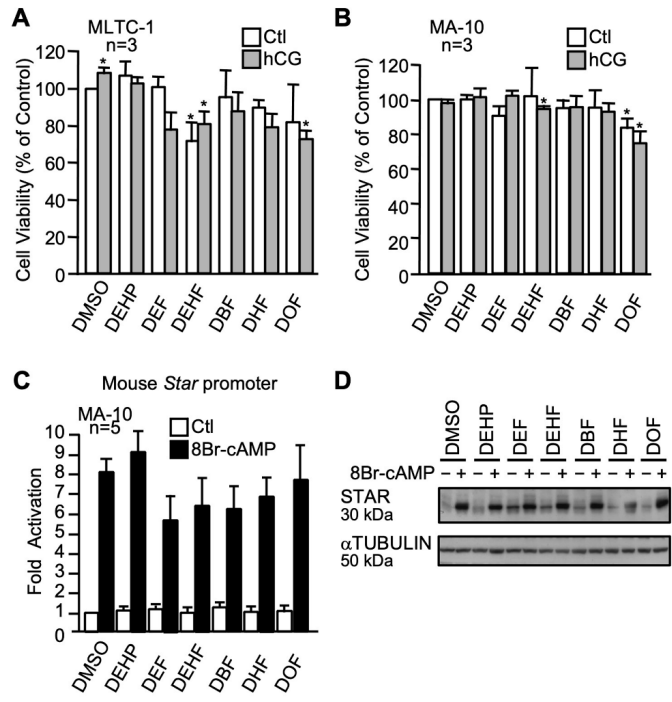

Figure 7. Effects of n-alkyl fumarate plasticizers on MA-10 and MLTC-1 Leydig cells. MA-10 (A) and MLTC-1 (B) cells were treated for $24 \mathrm{~h}$ with either dimethylsulfoxide (DMSO) or $100 \mu \mathrm{M}$ of $\mathrm{n}$-alkyl fumarate plasticizers as indicated in the presence (gray bars) or absence (white bars) of $20 \mathrm{ng} / \mathrm{mL}$ hCG and cell viability was determined by MTT assays. Values are the mean of three individual experiments, each performed in triplicate $( \pm S E M)$. (C) MA-10 Leydig cells were transfected with a $-980 \mathrm{bp}$ mouse Star reporter and treated with $100 \mu \mathrm{M}$ of the different n-alkyl fumarate plasticizers as indicated in the absence (white bars) or presence (black bars) of $0.1 \mathrm{mM}$ 8Br-cAMP. Results are shown as fold activation over control. Values are the mean of five individual experiments performed in triplicate $( \pm$ SEM). (D) STAR protein levels were determined in MA-10 Leydig cells treated with vehicle (DMSO) or the various n-alkyl fumarate plasticizers as indicated in the absence $(-)$ or presence $(+)$ of 8 Br-cAMP. $\alpha$ TUBULIN was used as a loading control. All experiments were repeated three times and produced similar results. ${ }^{*}: p \leq 0.05$. 
A

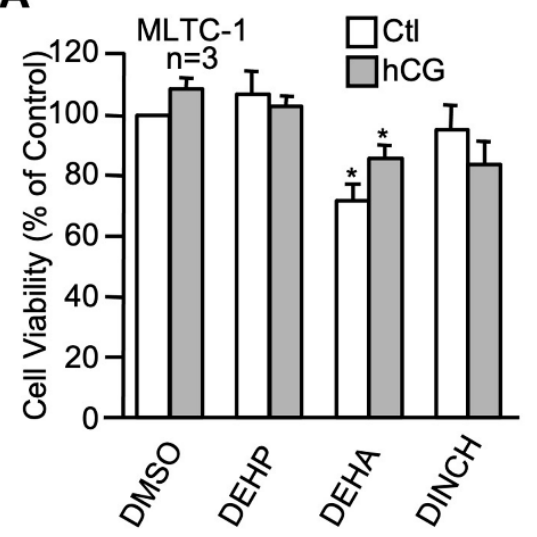

C

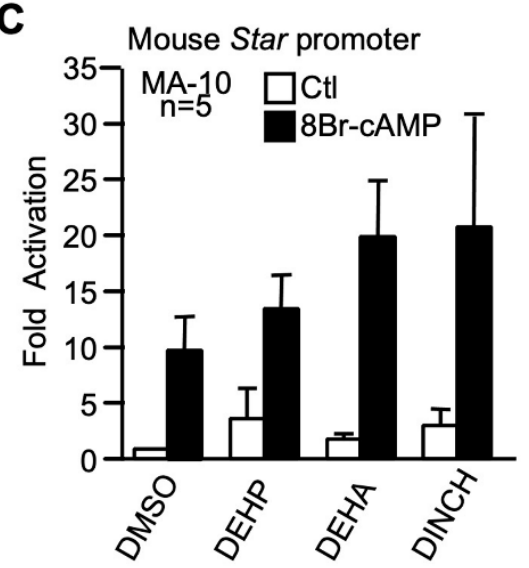

B

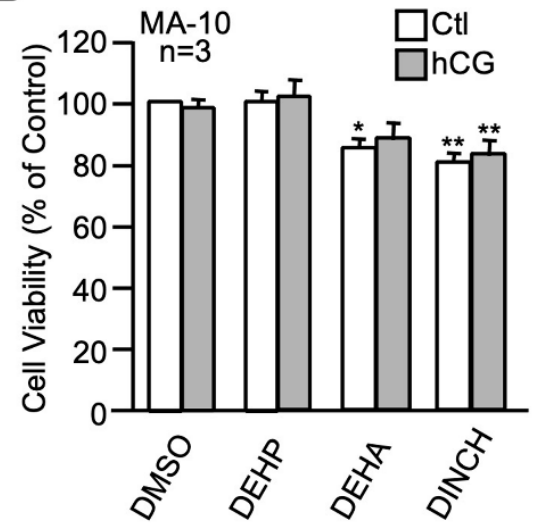

D

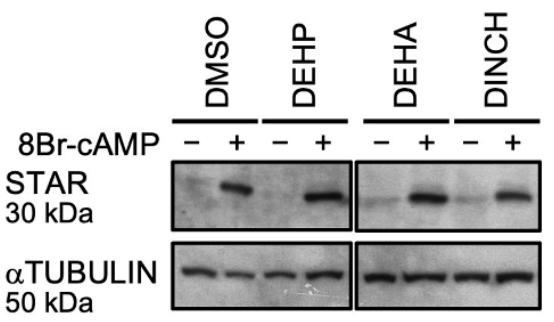

Figure 8. Effects of two commercial plasticizers on MA-10 and MLTC-1 Leydig cells. MLTC-1 (A) and MA-10 (B) Leydig cells were treated for $24 \mathrm{~h}$ with either DMSO or $100 \mu \mathrm{M}$ of two commercial plasticizers (DEHA and DINCH) in presence (gray bars) or absence (white bars) of $20 \mathrm{ng} / \mathrm{mL}$ of hCG and assayed for cell viability using a MTT assay. Values are the mean of three individual experiments each performed in triplicate ( \pm SEM). (C) MA-10 Leydig cells were transfected with a -980 bp mouse Star reporter and treated with $100 \mu \mathrm{M}$ of the two commercial plasticizers as indicated in the absence (white bars) or presence (black bars) of $0.1 \mathrm{mM}$ 8Br-cAMP. Results are shown as fold activation over control. Values are the mean of five individual experiments performed in triplicate ( \pm SEM). (D) STAR protein levels were determined in MA-10 Leydig cells treated with vehicle (DMSO) or the two commercial plasticizers as indicated in the absence (-) or presence (+) of 8Br-cAMP. $\alpha$ TUBULIN was used as a loading control. All experiments were repeated three times and produced similar results. *: $p \leq 0.05,{ }^{* *}: p \leq 0.01$.

\subsubsection{The n-alkyl Dibenzoate Plasticizer Series}

Three plasticizers with different carbon chain lengths were used and compared to DEHP: 1,3-propanediol dibenzoate (C3DB), 1,5-pentanediol dibenzoate (C5DB), and 1,6hexanediol dibenzoate (C6DB). Overall, cell viability of both MLTC-1 (Figure 4A) and MA-10 (Figure 4B) Leydig cell viability was not dramatically impaired by any of the n-alkyl dibenzoate plasticizers at $100 \mu \mathrm{M}$, although some small increases or decreases were noted. Luciferase gene reporter assays with the mouse Star promoter showed that all the n-alkyl dibenzoate plasticizers tested did not affect either basal or cAMP-induced Star promoter activity in MA-10 Leydig cells (Figure 4C). Consistent with this, all the n-alkyl dibenzoate plasticizers tested did not affect basal and cAMP-induced STAR protein levels in MA-10 Leydig cells (Figure 4D). 


\subsubsection{The n-alkyl Succinate Plasticizer Series}

For this plasticizer series, five different succinate derivatives were used at $100 \mu \mathrm{M}$ and compared to $100 \mu \mathrm{M}$ DEHP: dibutyl succinate (DBS), diethyl succinate (DES), diethylhexyl succinate (DEHS), dihexyl succinate (DHS), and dioctyl succinate (DOS). Although there was a tendency of reduced cell viability for some plasticizers (DEHS and DOS in MLTC-1), these effects did not reach statistical significance. Therefore, none of the five n-alkyl succinate plasticizers affected cell viability of both MLTC-1 (Figure 5A) and MA-10 (Figure 5B) Leydig cells in the presence of hCG or vehicle. The activity of the mouse Star promoter, either basal or CAMP-induced, was not affected by most of the n-alkyl succinate plasticizers, as revealed by transient transfection assays in MA-10 Leydig cells (Figure 5C). A statistically significant increase in cAMP-responsiveness was observed with DBS (17-fold compared to 9-fold for the control) while DHS significantly repressed the cAMP-induced stimulation (7-fold compared to 9-fold for the control). Basal and cAMP-induced STAR protein levels, however, were not affected by any of the five n-alkyl succinate plasticizers tested (Figure 5D).

\subsubsection{The n-alkyl Maleate Plasticizer Series}

Five maleate plasticizers with different carbon chain lengths were used at a concentration of $100 \mu \mathrm{M}$ and compared to DEHP: dibutyl maleate (DBM), diethyl maleate (DEM), diethylhexyl maleate (DEHM), dihexyl maleate (DHM), and dioctyl maleate (DOM). As shown in Figure 6A, a significant decrease in cell viability was observed in MLTC-1 Leydig cells after exposure to diethylhexyl maleate (DEHM) and dihexyl maleate (DHM) following hCG stimulation and with dioctyl maleate (DOM) in unstimulated cells only. However, no significant effect on the viability of MA-10 Leydig cells was observed with any of the n-alkyl maleate plasticizers (Figure 6B). In luciferase reporter assays, none of the n-alkyl maleate plasticizers repressed basal or cAMP-induced Star promoter activity in MA-10 Leydig cells (Figure 6C), while a slight but statistically significant increase in cAMP responsiveness was observed with diethylhexyl maleate (DEHM), dibutyl maleate (BDM), and dihexyl maleate (DHM). Basal and cAMP-induced STAR protein levels remained unchanged after exposure to the maleate plasticizers in MA-10 Leydig cells (Figure 6D).

\subsubsection{The n-alkyl Fumarate Plasticizer Series}

Five fumarate plasticizers that differ by the length of their carbon chain were used at a concentration of $100 \mu \mathrm{M}$ and compared to DEHP: dibutyl fumarate (DBF), diethyl fumarate (DEF), diethylhexyl fumarate (DEHF), dihexyl fumarate (DHF), and dioctyl fumarate (DOF). The viability of MLTC-1 Leydig cells was significantly impaired by DEHF (basal and hCGstimulated) and DOF (in the presence of $\mathrm{hCG}$ ) while the other fumarate plasticizers did not reduce cell viability (Figure 7A). MA-10 Leydig cell viability was only affected by DOF (basal and in the presence of hCG) and DEHF (in the presence of hCG) (Figure 7B). As revealed by luciferase reporter assays, none of the fumarate plasticizers affected basal and cAMP-induced Star promoter activity (Figure 7C). Western blots revealed that the n-alkyl fumarate plasticizers affected basal or cAMP-induced STAR protein levels to a different extent in MA-10 Leydig cells (Figure 7D). DBF, DEF, DEHF, and DHF increased basal STAR protein levels (Figure 7D). Exposure to DHF led to a decrease in cAMP-induced STAR protein levels (Figure 7D).

\subsubsection{The Commercial Plasticizers Hexamoll-DINCH and DEHA}

We next evaluated the impact of $100 \mu \mathrm{M}$ of two commercial plasticizers, HexamollDINCH and diethylhexyl adipate (DEHA), on Leydig cells. When compared with the control (DMSO), DEHA caused a decrease in cell viability in unstimulated and hCGstimulated MLTC-1 cells (Figure 8A) while both Hexamoll-DINCH and DEHA caused a decrease in cell viability in unstimulated and hCG-stimulated MA-10 cells (Figure 8B). Luciferase reporter assays in MA-10 Leydig cells showed that DEHA and Hexamoll-DINCH 
do not significantly affect basal or cAMP-induced Star promoter activity (Figure 8C). STAR protein levels were not affected by the two commercial plasticizers (Figure 8D).

\subsection{Effect of Two Novel Candidate Plasticizers on Leydig Cell Line Function and FDXR Levels}

We next assessed the impact of the C6DB and DOS candidate plasticizers $(100 \mu \mathrm{M})$ on testosterone production by MLTC-1 Leydig cells. As shown in Figure 9A, exposure to DOS and $\mathrm{C} 6 \mathrm{DB}$ did not affect testosterone production when compared to the control (DMSO). Finally, the effect of C6DB and DOS on FDXR protein levels, identified as a new target of MEHP, was assessed. As shown in Figure 9B, C6DB and DOS have no effect on FDXR protein levels.

A

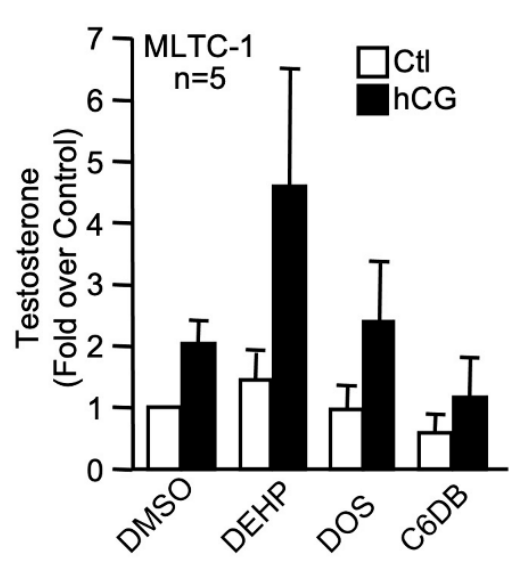

B

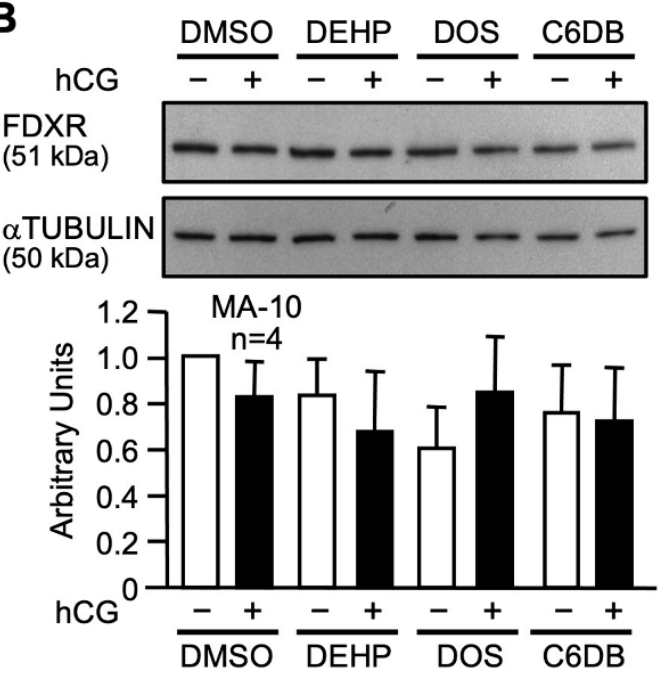

Figure 9. Effects of two green plasticizer candidates on Leydig cells steroidogenesis. (A) MLTC-1 Leydig cells treated with dimethylsulfoxide (DMSO) or $100 \mu \mathrm{M}$ of DEHP, DOS, or C6DB in the absence (white bars) or presence (black bars) of $20 \mathrm{ng} / \mathrm{mL}$ hCG and testosterone levels in the media were determined by ELISA. Values are the mean of five individual experiments each performed in duplicate ( \pm SEM). (B) MA-10 Leydig cells were treated with dimethylsulfoxide (DMSO) or $100 \mu \mathrm{M}$ of DEHP, DOS, or C6DB in the absence (-) or presence (+) of $20 \mathrm{ng} / \mathrm{mL}$ hCG and whole cell extracts were prepared for immunodetection of the FDXR protein. $\alpha$ TUBULIN was used as a loading control. All experiments were repeated four times and produced similar results. Values are the mean of densitometry of the four individual experiments $( \pm$ SEM).

\section{Discussion}

This study was designed to provide a better understanding of the molecular mechanisms of MEHP action in the inhibition of Leydig cells steroidogenesis and to assess the effects of novel plasticizers as alternatives to DEHP.

\subsection{MEHP Represses Leydig Cells Steroidogenesis by Decreasing Star Gene Transcription}

Numerous studies performed in rodents or using whole testis and Leydig cell lines have all shown that MEHP (the active metabolite of DEHP) negatively affects steroidogenesis [20,35,39-42]. Most cell line studies on the effect of MEHP on steroidogenesis were performed in the MA-10 Leydig cell line. Although a suitable model for studying the early steps of steroidogenesis, the MA-10 cell line produces mainly progesterone due to low and / or poorly active CYP17A1 [61], which makes it less suitable for studying the later steps of steroidogenesis. However, the MLTC-1 Leydig cell line has the ability to produce testosterone and constitutes an excellent model to characterize the impact of MEHP on the entire steroidogenic pathway. In our present study, exposure of both Leydig cell lines to $100 \mu \mathrm{M}$ MEHP reduced hormone-induced testosterone and progesterone production by about 25 and $50 \%$, respectively, without affecting the viability of the cells. We also observed a tendency towards increased basal steroidogenesis (without hCG stimulation), 
which is in agreement with other reports describing a stimulatory action of MEHP on basal steroidogenesis $[62,63]$. Interestingly, exposure to MEHP significantly decreased progesterone production more than testosterone, which indicates that MEHP may target the early steps of steroidogenesis more efficiently.

It is well established that MEHP represses Leydig cell steroidogenesis by decreasing STAR mRNA and protein levels, leading to a reduction in testosterone production [40-42,51,52]. Consistent with this, exposure of Leydig cells to MEHP was found to cause an increase in the number of lipid droplets, especially in hCG-treated cells ([64] and our unpublished data). Such an increase in lipid droplet content is consistent with a reduction in the activity of the cholesterol transport machinery, which includes the STAR protein. The mechanisms by which exposure to MEHP leads to reduced Star expression remain poorly characterized. In our present work, we found that exposure to MEHP significantly repressed cAMPinduced Star promoter activity while having no effect on basal Star promoter activity. This indicates that the MEHP-mediated reduction in STAR mRNA and protein levels is due, at least in part, to a decrease in hormone responsiveness of the Star promoter. An effect of MEHP on Star mRNA stability, however, cannot be excluded and more experiments are required to explore this possibility. Our functional promoter assays revealed that the MEHP-responsive region is located within the proximal region (-95 bp) of the Star promoter, a region that contains binding sites for several transcription factors important for Star expression including SF1, NUR77, C/EBP $\beta$, GATA4, AP1 (cJUN/cFOS), and COUPTFII $[44,65-73]$. When the protein levels of two transcription factors, SF1 and C/EBP $\beta$, were assessed, no effects of MEHP were observed. Interestingly, another phthalate, MBP, was found to significantly reduce SF1 protein levels in MLTC-1 cells, although much higher concentrations $(400,800 \mu \mathrm{M})$ of MBP were used [74]. Our data on the action of MEHP on the Star promoter indicate that MEHP either targets other transcription factors known to act within this promoter region, affects post-translational modifications such as phosphorylation of any of these factors, or modulates their DNA-binding activity without affecting protein levels. Similar mechanisms were proposed for MBP, which was found to reduce GATA4 phosphorylation levels [74]. Further studies are needed to test these possibilities for MEHP action. Altogether, these data suggest that different phthalates might have different mechanisms of action to repress steroidogenesis in Leydig cells.

\subsection{MEHP Reduces FDXR Protein Levels in Leydig Cells}

Once cholesterol has reached the inner mitochondrial membrane, the next step is the conversion of cholesterol into pregnenolone. This reaction requires the action of two key proteins: CYP11A1 and FDXR. CYP11A1 is a mitochondrial enzyme that catalyzes the conversion of cholesterol into pregnenolone (reviewed in $[50,75,76])$. Ferredoxin reductase (FDXR, also known as adrenodoxin reductase, ADXR) is a mitochondrial FAD flavoprotein involved in the conversion of NADPH to NADP, a reaction that is essential for steroidogenesis since the electrons it produces are transferred to CYP11A1 and are required for its activity [76]. We found that CYP11A1 protein levels were unaffected by MEHP. On the other hand, FDXR protein levels dramatically decreased in the presence of MEHP to about $30 \%$ of control after cAMP treatment. Our identification of FDXR as a novel target of MEHP validates the hypothesis of Gunnarsson et al., who suggested that another site of MEHP action might exist prior to the formation of pregnenolone in the mitochondria [62].

Exposure of Leydig cells to MEHP is also known to cause a significant increase in the production of reactive oxygen species (ROS), further affecting Leydig cell function [52,55]. The exact mechanisms of increased ROS production remain to be elucidated. However, recent reports have revealed that reduced FDXR function in patients harboring hypomorphic mutations in the FDXR gene or in Fdxr mutant mice was associated with impairment of the electron transport chain, along with a significant increase in the production of ROS [77-79]. Our findings that exposure to MEHP reduces FDXR levels provide a mechanism to explain, at least in part, the MEHP-mediated increase in ROS production in Leydig cells. 


\subsection{Effects of Novel Candidate Plasticizers on Leydig Cell Steroidogenesis}

Because of the detrimental effects of phthalates on male reproductive function, and the high cost associated with some of the currently used replacements, it became important to test novel candidate plasticizers. We tested the effects of four series of novel plasticizers (nalkyl dibenzoate, $\mathrm{n}$-alkyl diester succinate, $\mathrm{n}$-alkyl diester maleate, $\mathrm{n}$-alkyl diester fumarate) along with two commercially available plasticizers (Hexamoll-DINCH and DEHA) on Star promoter activity and STAR protein levels in Leydig cell lines.

None of the compounds in the dibenzoate series affected basal or cAMP-induced mouse Star promoter activity and STAR protein levels in MA-10 Leydig cells. This is in agreement with data from Boisvert et al., who reported that none of the dibenzoate plasticizers affected hormone-induced progesterone production in MA-10 Leydig cells [80]. However, a small decrease in cell viability was observed with 1,6 hexanediol dibenzoate (C6DB) and 1,3-propanediol dibenzoate (C3DB) in MLTC-1 and MA-10 Leydig cells, respectively. Despite the fact that C6DB caused slight toxicity in MLTC-1, it was chosen as a candidate green plasticizer because it is readily biodegraded by microorganisms and the monoesters produced are also quickly metabolized [81,82]. Furthermore, C6BD was not found to leach out of PVC compared to the other dibenzoate plasticizers and to DEHP [83].

For the succinate series, none were found to affect the viability of Leydig cells. In addition, most succinate plasticizers had no effect on Star promoter activity (basal or cAMP-induced) except for a small decrease observed in cAMP induction after treatment with dihexyl succinate (DHS). In agreement with our findings, succinate-derived plasticizers were also reported to have no effect on hCG-induced progesterone production [80]. Additionally, Kastner et al. reported that among that family of plasticizers, DOS has a very low ability to leach out from PVC [83]. The fact that DOS is not toxic to Leydig cells, does not affect steroidogenesis, and has a low potential to leach makes it an excellent replacement candidate.

For the maleate series, we found that several compounds negatively affected MLTC1 Leydig cell viability. However, no inhibitory effects were observed on Star promoter activity or STAR protein levels following exposure to the maleate-derived plasticizers. On the other hand, Boisvert et al. reported that several of the maleate plasticizers caused a significant reduction in hormone-induced progesterone production in MA-10 Leydig cells [80]. These data, combined with our current data showing a lack of effects on Star expression, indicate that maleate-derived plasticizers affect steroidogenesis at a step after STAR action. Despite their desirable physicochemical properties [83], maleate plasticizers were found to be biodegraded as slowly as DEHP [58]. Based on these data, maleate plasticizers were eliminated from the list of potential plasticizers.

With respect to the fumarate series, several were toxic in both Leydig cell lines and negatively affected STAR protein levels. This is in agreement with the fact that several fumarate-derived plasticizers were found to significantly repress hormone-induced progesterone production in MA-10 cells [80]. In addition, they were reported to leach out of PVC after 3 weeks and displayed poor plasticizing properties [58]. These results indicate that fumarate plasticizers should be excluded from the list of potential phthalate alternatives.

The two commercial plasticizers tested, Hexamoll-DINCH and DEHA, were previously found not to leach out of PVC [83]. We found that both compounds decreased the viability of MA-10 and MLTC-1 Leydig cells. Similar results were obtained for DINCH by Boisvert et al. in MA-10 cells and they also reported that DINCH represses hormoneinduced progesterone production in these cells [80]. Additional studies on these two compounds should be performed to fully assess their impact on male reproductive health

Based on our present findings and data from the literature [80], two plasticizers (DOS and $\mathrm{C} 6 \mathrm{DB}$ ) were chosen for further examination. Basal and hormone-induced testosterone production, and evaluation of FDXR protein levels, revealed that DOS and C6DB did not significantly affect these Leydig cell parameters. This is consistent with two animal studies which reported that DOS had no significant systemic effects [84,85], suggesting that it could be a viable alternative plasticizer. 
In conclusion, our data revealed that MEHP represses Leydig cell steroidogenesis by disrupting two of the earliest steps of steroidogenesis. The primary site of MEHP action seems to be the hormone-induced transport of cholesterol inside mitochondria by disrupting Star transcription, while another site of action includes the disruption of cholesterol conversion into pregnenolone by decreasing FDXR protein levels. Furthermore, two chemicals with desirable plasticizer properties, C6DB and DOS, were found to have no effect on Leydig cell steroidogenesis (STAR promoter activity, STAR and FDXR protein levels, testosterone production). Finally, our data also validated the MA-10 and MLTC-1 Leydig cell lines as two appropriate models for the study of MEHP action on steroidogenesis.

\section{Materials and Methods}

\subsection{Chemicals}

Di(2-ethylhexyl)phthalate (DEHP) and 8-bromo-cAMP (8Br-cAMP) were purchased from Sigma-Aldrich Canada (Oakville, Ontario, Canada). DEHP was dissolved in dimethyl sulfoxide (DMSO) purchased from Sigma-Aldrich Canada (Oakville, Ontario, Canada). MEHP (99\% purity) was purchased from AccuStandard (New Haven, CT, USA) and dissolved in 99\% ethanol. The new candidate plasticizers were provided by Dr. David G. Cooper (McGill University, Montréal, Canada) [57,58] and diluted in DMSO.

\subsection{Cell Culture}

Mouse tumor MA-10 Leydig cells [86] were provided by Dr. Mario Ascoli (University of Iowa, Iowa City, IA, USA) and cultured in Dulbecco's Modified Eagle Medium-F12 (DMEM-F12) supplemented with penicillin and streptomycin and $15 \%$ horse serum and incubated at $37^{\circ} \mathrm{C}$ in $5 \% \mathrm{CO}_{2}$. Mouse tumor MLTC-1 Leydig cells were purchased from American Type Culture Collection (ATCC) and cultured in Dulbecco's Modified Eagle Medium (DMEM) supplemented with penicillin and streptomycin and $10 \%$ fetal bovine serum (FBS) and incubated at $37^{\circ} \mathrm{C}$ in $5 \% \mathrm{CO}_{2}$. The phenotype of both MA-10 and MLTC-1 cell lines was ascertained by monitoring cell morphology and determining steroid hormone production. For all experiments, MA-10 and MLTC- 1 were used between passages P10 and P25. For plasticizer treatments, cells were cultured in media containing charcoal-treated serum and treated with vehicle (DMSO or $\mathrm{EtOH}$, none of which affects cell viability at the concentrations used) or $100 \mu \mathrm{M}$ of plasticizer (DEHP/MEHP or new plasticizers). Twenty hours later, cells were stimulated with $0.1 \mathrm{mM} 8 \mathrm{Br}-\mathrm{cAMP}$ or hCG $20 \mathrm{ng} / \mathrm{mL}$ (LH analog) for $4 \mathrm{~h}$.

\subsection{Plasmids, Transfections and Luciferase Reporter Assays}

The $-980,-195,-144,-104,-95,-70$ and -43 bp to +17 bp mouse Star promoter constructs were described previously [44,87]. MA-10 Leydig cells were seeded in 24-well plates at 150,000 cells per well and transfected the next day with $500 \mathrm{ng}$ of reporter plasmid using JetPrime (PolyPlus-Transfections Inc., Illkirch, France) as described by the manufacturer. Cells were then lysed, and lysates analyzed as previously described $[44,87]$. These experiments were performed at least five times, each in triplicate.

\subsection{Protein Purification and Western Blot}

MA-10 Leydig cells were seeded in 6-well plates at 500,000 cells per well and treated as described above. Treated cells were rinsed twice with phosphate-buffered saline (PBS) and harvested for total protein extractions. Total proteins were isolated by lysing the cells with RIPA buffer [50 mM Tris- $\mathrm{HCl}$ (pH 7.5), 0.5\% Igepal, $150 \mathrm{mM} \mathrm{NaCl}, 1 \mathrm{mM}$ EDTA, $1 \mathrm{mM}$ dithiothreitol (DTT), $0.5 \mathrm{mM}$ phenylmethanesulfonyl fluoride (PMSF), $10 \mu \mathrm{g} / \mathrm{mL}$ aprotinin, $1 \mu \mathrm{g} / \mathrm{mL}$ leupeptin, and $1 \mu \mathrm{g} / \mathrm{mL}$ pepstatin] for $20 \mathrm{~min}$ at $4{ }^{\circ} \mathrm{C}$, followed by one $10 \mathrm{~s}$ sonication pulse and centrifugation to remove cell debris. Protein concentrations were estimated using standard Bradford assay. Fifteen micrograms of total proteins were boiled for $2 \mathrm{~min}$ in a denaturing loading buffer [ $20 \%$ glycerol, $4 \%$ SDS, $100 \mathrm{mM}$ Tris pH 6.8, 0.002\% bromophenol blue, $4 \% \beta$-mercaptoethanol], separated by SDS-PAGE, and transferred onto 
polyvinylidene difluoride (PVDF) membrane (Millipore, Bedford, MA, USA). For STAR and $\alpha$ TUBULIN, immunodetection was performed using an avidin-biotin approach according to the manufacturer's instructions (Vector Laboratories, Inc., Ontario, Canada). For FDXR, CYP11A1, C/EBP $\beta$ and SF1 immunodetection, ECL-HRP detection kit (GE healthcare life sciences, Buckinghamshire, UK) was used according to the manufacturer's instructions. Detection of STAR, FDXR, CYP11A1, C/EBP $\beta$, SF1 and $\alpha$ TUBULIN was performed using an anti-STAR antiserum (FL-285, 1:1000 dilution, $200 \mathrm{ng} / \mathrm{mL}$; Santa Cruz Biotechnologies, Santa Cruz, CA, USA), an anti-FDXR antiserum (sc-25846, 1:1000 dilution, $200 \mathrm{ng} / \mathrm{mL}$; Santa Cruz Biotechnologies, Santa Cruz, CA, USA), an anti-CYP11A1 antiserum (sc-18043, 1:200 dilution, $200 \mathrm{ng} / \mathrm{mL}$; Santa Cruz Biotechnologies, Santa Cruz, CA, USA), an antiC/EBP $\beta$ antiserum (sc-150x, 1:5000 dilution, 400 ng/mL; Santa Cruz Biotechnologies, Santa Cruz, CA, USA), an anti-SF1 antiserum (1:1000 dilution, $1 \mu \mathrm{g} / \mathrm{mL}$; ABR Affinity BioReagents, Golden, CO, USA) and a monoclonal anti- $\alpha$ TUBULIN antibody (1:10000 dilution, $600 \mathrm{ng} / \mathrm{mL}$; Sigma-Aldrich Canada, Oakville, Ontario, Canada). $\alpha$ TUBULIN was used as a loading control. All experiments were repeated at least four times and produced similar results.

\subsection{Progesterone and Testosterone Quantification}

ELISA for progesterone and testosterone were performed using an EIA kit as recommended by the manufacturer (Cayman Chemical, Ann Arbor, MI, USA) as described in [88-90].

\subsection{MTT Cell Assay}

MA-10 and MLTC-1 Leydig cells were seeded in 96-well plates at 10,000 cells per well. The next day, cells (20,000 cells) were treated as described above in the cell culture section. The MTT cell assay measuring mitochondrial integrity and cell viability was performed as recommended by the manufacturer (Biotium, Hayward, Berkeley Heights, NJ, USA).

\subsection{Statistical Analysis}

For all single comparisons between two experimental groups, paired Student's $t$ tests were performed. For multiple group comparisons, statistical analyses were performed using one-way ANOVA followed by the Newman-Keuls post hoc test. For all statistical analyses, $p \leq 0.05$ was considered significant. All statistical analyses were performed using GraphPad Prism software (La Jolla, CA, USA).

Author Contributions: A.N.E.N. performed all the experiments. J.J.T. conceived the original idea and supervised the project. A.N.E.N. drafted the manuscript with support from J.J.T. All authors provided critical feedback and helped shape the research, analysis, and manuscript. All authors have read and agreed to this version of the manuscript.

Funding: This research was funded by grants from the Canadian Institutes of Health Research (CIHR) (funding reference number MOP-81387) and from the CIHR Institute of Human Development, Child and Youth Health (funding reference number RHF-100626) to J.J.T.

Institutional Review Board Statement: Not applicable.

Informed Consent Statement: Not applicable.

Data Availability Statement: All data generated or analyzed during this study are included in this article.

Acknowledgments: We would like to thank Mario Ascoli for generously providing the MA-10 Leydig cell line used in this study and David G. Cooper for providing the new plasticizer candidates.

Conflicts of Interest: The authors declare no conflict of interest. 


\section{References}

1. Schettler, T. Human exposure to phthalates via consumer products. Int. J. Androl. 2006, 29, 134-139. [CrossRef]

2. Wormuth, M.; Scheringer, M.; Vollenweider, M.; Hungerbuhler, K. What are the sources of exposure to eight frequently used phthalic acid esters in Europeans? Risk Anal. 2006, 26, 803-824. [CrossRef]

3. Fierens, T.; Servaes, K.; Van Holderbeke, M.; Geerts, L.; De Henauw, S.; Sioen, I.; Vanermen, G. Analysis of phthalates in food products and packaging materials sold on the Belgian market. Food Chem. Toxicol. 2012, 50, 2575-2583. [CrossRef]

4. Guart, A.; Bono-Blay, F.; Borrell, A.; Lacorte, S. Migration of plasticizers phthalates, bisphenol A and alkylphenols from plastic containers and evaluation of risk. Food Addit. Contam. Part. Chem. Anal. Control. Expo. Risk Assess. 2011, 28, 676-685. [CrossRef]

5. Koniecki, D.; Wang, R.; Moody, R.P.; Zhu, J. Phthalates in cosmetic and personal care products: Concentrations and possible dermal exposure. Environ. Res. 2011, 111, 329-336. [CrossRef]

6. Guo, Y.; Kannan, K. A survey of phthalates and parabens in personal care products from the United States and its implications for human exposure. Environ. Sci. Technol. 2013, 47, 14442-14449. [CrossRef]

7. Babich, M.A.; Chen, S.B.; Greene, M.A.; Kiss, C.T.; Porter, W.K.; Smith, T.P.; Wind, M.L.; Zamula, W.W. Risk assessment of oral exposure to diisononyl phthalate from children's products. Regul. Toxicol. Pharmacol. 2004, 40, 151-167. [CrossRef]

8. Wilkinson, C.F.; Lamb, J.C.T. The potential health effects of phthalate esters in children's toys: A review and risk assessment. Regul. Toxicol. Pharmacol. 1999, 30, 140-155. [CrossRef]

9. Witorsch, R.J.; Thomas, J.A. Personal care products and endocrine disruption: A critical review of the literature. Crit. Rev. Toxicol. 2010, 40, 1-30. [CrossRef]

10. Net, S.; Sempere, R.; Delmont, A.; Paluselli, A.; Ouddane, B. Occurrence, fate, behavior and ecotoxicological state of phthalates in different environmental matrices. Environ. Sci. Technol. 2015, 49, 4019-4035. [CrossRef]

11. Luis, C.; Algarra, M.; Camara, J.S.; Perestrelo, R. Comprehensive Insight from Phthalates Occurrence: From Health Outcomes to Emerging Analytical Approaches. Toxics 2021, 9, 157. [CrossRef]

12. Wang, Y.; Qian, H. Phthalates and Their Impacts on Human Health. Healthcare 2021, 9, 603. [CrossRef]

13. Strauss, A.A. Di(2-ethylhexyl)phthalate (DEHP). J. Pediatr. Pharmacol. Ther. 2004, 9, 89-95. [CrossRef]

14. Erythropel, H.C.; Maric, M.; Nicell, J.A.; Leask, R.L.; Yargeau, V. Leaching of the plasticizer di(2-ethylhexyl)phthalate (DEHP) from plastic containers and the question of human exposure. Appl. Microbiol. Biotechnol. 2014, 98, 9967-9981. [CrossRef]

15. Wang, Y.; Zhu, H.; Kannan, K. A Review of Biomonitoring of Phthalate Exposures. Toxics 2019, 7, 21. [CrossRef]

16. Toxicology Excellence for Risk Assessment (TERA). Exposure Assessment: Composition, Production, and Use of Phthalates; University of Cincinnati: Cincinnati, OH, USA, 2015; pp. 1-180.

17. Huang, S.; Qi, Z.; Ma, S.; Li, G.; Long, C.; Yu, Y. A critical review on human internal exposure of phthalate metabolites and the associated health risks. Environ. Pollut. 2021, 279, 116941. [CrossRef]

18. Institute for Health and Consumer Protection. European Union Risk Assessment Report on Bis(2-ethylhexyl) Phthalate (DEHP); Office for Official Publications of the European Communities: Luxembourg, 2008; pp. 1-588.

19. Wittassek, M.; Koch, H.M.; Angerer, J.; Bruning, T. Assessing exposure to phthalates-The human biomonitoring approach. Mol. Nutr. Food Res. 2011, 55, 7-31. [CrossRef]

20. Heudorf, U.; Mersch-Sundermann, V.; Angerer, J. Phthalates: Toxicology and exposure. Int. J. Hyg. Environ. Health 2007, 210, 623-634. [CrossRef]

21. Koch, H.M.; Drexler, H.; Angerer, J. An estimation of the daily intake of di(2-ethylhexyl)phthalate (DEHP) and other phthalates in the general population. Int. J. Hyg. Environ. Health 2003, 206, 77-83. [CrossRef]

22. Koch, H.M.; Preuss, R.; Angerer, J. Di(2-ethylhexyl)phthalate (DEHP): Human metabolism and internal exposure-An update and latest results. Int. J. Androl. 2006, 29, 155-165. [CrossRef]

23. Frederiksen, H.; Skakkebaek, N.E.; Andersson, A.M. Metabolism of phthalates in humans. Mol. Nutr. Food Res. 2007, 51, 899-911. [CrossRef]

24. Silva, M.J.; Barr, D.B.; Reidy, J.A.; Kato, K.; Malek, N.A.; Hodge, C.C.; Hurtz, D., 3rd; Calafat, A.M.; Needham, L.L.; Brock, J.W. Glucuronidation patterns of common urinary and serum monoester phthalate metabolites. Arch. Toxicol. 2003, 77, 561-567. [CrossRef]

25. Vo, T.T.; Jung, E.M.; Dang, V.H.; Jung, K.; Baek, J.; Choi, K.C.; Jeung, E.B. Differential effects of flutamide and di-(2-ethylhexyl) phthalate on male reproductive organs in a rat model. J. Reprod. Dev. 2009, 55, 400-411. [CrossRef]

26. Vo, T.T.; Jung, E.M.; Dang, V.H.; Yoo, Y.M.; Choi, K.C.; Yu, F.H.; Jeung, E.B. Di-(2 ethylhexyl) phthalate and flutamide alter gene expression in the testis of immature male rats. Reprod. Biol. Endocrinol. 2009, 7, 104. [CrossRef]

27. Andrade, A.J.; Grande, S.W.; Talsness, C.E.; Gericke, C.; Grote, K.; Golombiewski, A.; Sterner-Kock, A.; Chahoud, I. A dose response study following in utero and lactational exposure to di-(2-ethylhexyl) phthalate (DEHP): Reproductive effects on adult male offspring rats. Toxicology 2006, 228, 85-97. [CrossRef]

28. Venturelli, A.C.; Meyer, K.B.; Fischer, S.V.; Kita, D.H.; Philipsen, R.A.; Morais, R.N.; Martino Andrade, A.J. Effects of in utero and lactational exposure to phthalates on reproductive development and glycemic homeostasis in rats. Toxicology 2019, 421, 30-40. [CrossRef]

29. Li, H.; Spade, D.J. Environmental exposures, fetal testis development and function: Phthalates and beyond. Reproduction 2021, 162, F147-F167. [CrossRef] 
30. Foster, P.M. Disruption of reproductive development in male rat offspring following in utero exposure to phthalate esters. Int. J. Androl. 2006, 29, 140-147. [CrossRef]

31. Gray, L.E., Jr.; Ostby, J.; Furr, J.; Price, M.; Veeramachaneni, D.N.; Parks, L. Perinatal exposure to the phthalates DEHP, BBP, and DINP, but not DEP, DMP, or DOTP, alters sexual differentiation of the male rat. Toxicol. Sci. 2000, 58, 350-365. [CrossRef]

32. Parks, L.G.; Ostby, J.S.; Lambright, C.R.; Abbott, B.D.; Klinefelter, G.R.; Barlow, N.J.; Gray, L.E., Jr. The plasticizer diethylhexyl phthalate induces malformations by decreasing fetal testosterone synthesis during sexual differentiation in the male rat. Toxicol. Sci. 2000, 58, 339-349. [CrossRef]

33. Howdeshell, K.L.; Rider, C.V.; Wilson, V.S.; Gray, L.E., Jr. Mechanisms of action of phthalate esters, individually and in combination, to induce abnormal reproductive development in male laboratory rats. Environ. Res. 2008, 108, 168-176. [CrossRef]

34. Christiansen, S.; Boberg, J.; Axelstad, M.; Dalgaard, M.; Vinggaard, A.M.; Metzdorff, S.B.; Hass, U. Low-dose perinatal exposure to di(2-ethylhexyl) phthalate induces anti-androgenic effects in male rats. Reprod. Toxicol. 2010, 30, 313-321. [CrossRef]

35. Culty, M.; Thuillier, R.; Li, W.; Wang, Y.; Martinez-Arguelles, D.B.; Benjamin, C.G.; Triantafilou, K.M.; Zirkin, B.R.; Papadopoulos, V. In utero exposure to di-(2-ethylhexyl) phthalate exerts both short-term and long-lasting suppressive effects on testosterone production in the rat. Biol. Reprod. 2008, 78, 1018-1028. [CrossRef]

36. Desdoits-Lethimonier, C.; Albert, O.; Le Bizec, B.; Perdu, E.; Zalko, D.; Courant, F.; Lesne, L.; Guille, F.; Dejucq-Rainsford, N.; Jegou, B. Human testis steroidogenesis is inhibited by phthalates. Hum. Reprod. 2012, 27, 1451-1459. [CrossRef]

37. Chang, W.H.; Li, S.S.; Wu, M.H.; Pan, H.A.; Lee, C.C. Phthalates might interfere with testicular function by reducing testosterone and insulin-like factor 3 levels. Hum. Reprod. 2015, 30, 2658-2670. [CrossRef]

38. Araki, A.; Mitsui, T.; Miyashita, C.; Nakajima, T.; Naito, H.; Ito, S.; Sasaki, S.; Cho, K.; Ikeno, T.; Nonomura, K.; et al. Association between maternal exposure to di(2-ethylhexyl) phthalate and reproductive hormone levels in fetal blood: The Hokkaido study on environment and children's health. PLoS ONE 2014, 9, e109039. [CrossRef]

39. Chauvigne, F.; Plummer, S.; Lesne, L.; Cravedi, J.P.; Dejucq-Rainsford, N.; Fostier, A.; Jegou, B. Mono-(2-ethylhexyl) phthalate directly alters the expression of Leydig cell genes and CYP17 lyase activity in cultured rat fetal testis. PLoS ONE 2011, 6, e27172. [CrossRef]

40. Chauvigne, F.; Menuet, A.; Lesne, L.; Chagnon, M.C.; Chevrier, C.; Regnier, J.F.; Angerer, J.; Jegou, B. Time- and dose-related effects of di-(2-ethylhexyl) phthalate and its main metabolites on the function of the rat fetal testis in vitro. Environ. Health Perspect. 2009, 117, 515-521. [CrossRef]

41. Svechnikov, K.; Svechnikova, I.; Soder, O. Inhibitory effects of mono-ethylhexyl phthalate on steroidogenesis in immature and adult rat Leydig cells in vitro. Reprod. Toxicol. 2008, 25, 485-490. [CrossRef]

42. Sekaran, S.; Jagadeesan, A. In utero exposure to phthalate downregulates critical genes in Leydig cells of F1 male progeny. J. Cell Biochem. 2015, 116, 1466-1477. [CrossRef]

43. Miller, W.L.; Auchus, R.J. The molecular biology, biochemistry, and physiology of human steroidogenesis and its disorders. Endocr. Rev. 2011, 32, 81-151. [CrossRef]

44. Martin, L.J.; Boucher, N.; Brousseau, C.; Tremblay, J.J. The orphan nuclear receptor NUR77 regulates hormone-induced StAR transcription in Leydig cells through a cooperation with CaMKI. Mol. Endocrinol. 2008, 22, 2021-2037. [CrossRef]

45. Stocco, D.M.; Wang, X.; Jo, Y.; Manna, P.R. Multiple signaling pathways regulating steroidogenesis and steroidogenic acute regulatory protein expression: More complicated than we thought. Mol. Endocrinol. 2005, 19, 2647-2659. [CrossRef]

46. Tremblay, J.J. Molecular regulation of steroidogenesis in endocrine Leydig cells. Steroids 2015, 103, 3-10. [CrossRef]

47. Stocco, D.M. The role of the StAR protein in steroidogenesis: Challenges for the future. J. Endocrinol. 2000, 164, 247-253. [CrossRef]

48. Issop, L.; Rone, M.B.; Papadopoulos, V. Organelle plasticity and interactions in cholesterol transport and steroid biosynthesis. Mol. Cell Endocrinol. 2013, 371, 34-46. [CrossRef]

49. Manna, P.R.; Stetson, C.L.; Slominski, A.T.; Pruitt, K. Role of the steroidogenic acute regulatory protein in health and disease. Endocrine 2016, 51, 7-21. [CrossRef]

50. Aghazadeh, Y.; Zirkin, B.R.; Papadopoulos, V. Pharmacological regulation of the cholesterol transport machinery in steroidogenic cells of the testis. Vitam. Horm. 2015, 98, 189-227.

51. Piché, C.D.; Sauvageau, D.; Vanlian, M.; Erythropel, H.C.; Robaire, B.; Leask, R.L. Effects of di-(2-ethylhexyl) phthalate and four of its metabolites on steroidogenesis in MA-10 cells. Ecotoxicol. Environ. Saf. 2012, 79, 108-115. [CrossRef]

52. Fan, J.; Traore, K.; Li, W.; Amri, H.; Huang, H.; Wu, C.; Chen, H.; Zirkin, B.; Papadopoulos, V. Molecular mechanisms mediating the effect of mono-(2-ethylhexyl) phthalate on hormone-stimulated steroidogenesis in MA-10 mouse tumor Leydig cells. Endocrinology 2010, 151, 3348-3362. [CrossRef]

53. Bui, T.T.; Giovanoulis, G.; Cousins, A.P.; Magner, J.; Cousins, I.T.; de Wit, C.A. Human exposure, hazard and risk of alternative plasticizers to phthalate esters. Sci. Total. Environ. 2016, 541, 451-467. [CrossRef]

54. Svechnikova, K.; Svechnikova, I.; Soder, O. Gender-Specific Adverse Effects of Mono-Ethylhexyl Phthalate on Steroidogenesis in Immature Granulosa Cells and Rat Leydig cell Progenitors in vitro. Front. Endocrinol. 2011, 2, 9. [CrossRef]

55. Zhou, L.; Beattie, M.C.; Lin, C.Y.; Liu, J.; Traore, K.; Papadopoulos, V.; Zirkin, B.R.; Chen, H. Oxidative stress and phthalateinduced down-regulation of steroidogenesis in MA-10 Leydig cells. Reprod. Toxicol. 2013, 42, 95-101. [CrossRef]

56. Clark, B.J.; Cochrum, R.K. The steroidogenic acute regulatory protein as a target of endocrine disruption in male reproduction. Drug. Metab. Rev. 2007, 39, 353-370. [CrossRef] 
57. Erythropel, H.C.; Dodd, P.; Leask, R.L.; Maric, M.; Cooper, D.G. Designing green plasticizers: Influence of alkyl chain length on biodegradation and plasticization properties of succinate based plasticizers. Chemosphere 2013, 91, 358-365. [CrossRef]

58. Erythropel, H.C.; Maric, M.; Cooper, D.G. Designing green plasticizers: Influence of molecular geometry on biodegradation and plasticization properties. Chemosphere 2012, 86, 759-766. [CrossRef]

59. Erythropel, H.C.; Brown, T.; Maric, M.; Nicell, J.A.; Cooper, D.G.; Leask, R.L. Designing greener plasticizers: Effects of alkyl chain length and branching on the biodegradation of maleate based plasticizers. Chemosphere 2015, 134, 106-112. [CrossRef]

60. Erythropel, H.C.; Shipley, S.; Börmann, A.; Nicell, J.A.; Maric, L.; Leask, R.L. Designing green plasticizers: Influence of molecule geometry and alkyl chain length on the plasticizing effectiveness of diester plasticizers in PVC blends. Polymer 2016, 89, 18-27. [CrossRef]

61. Ascoli, M. Immortalized Leydig Cell Lines as Models for Studying Leydig Cell Physiology. In The Leydig Cell in Health and Disease, 2nd ed.; Payne, A., Hardy, M.P., Eds.; Humana Press: Totowa, NJ, USA, 2007; pp. 373-381.

62. Gunnarsson, D.; Leffler, P.; Ekwurtzel, E.; Martinsson, G.; Liu, K.; Selstam, G. Mono-(2-ethylhexyl) phthalate stimulates basal steroidogenesis by a cAMP-independent mechanism in mouse gonadal cells of both sexes. Reproduction 2008, 135, 693-703. [CrossRef]

63. Savchuk, I.; Soder, O.; Svechnikov, K. Mono-2-ethylhexyl phthalate stimulates androgen production but suppresses mitochondrial function in mouse leydig cells with different steroidogenic potential. Toxicol. Sci. 2015, 145, 149-156. [CrossRef]

64. Dees, J.H.; Gazouli, M.; Papadopoulos, V. Effect of mono-ethylhexyl phthalate on MA-10 Leydig tumor cells. Reprod. Toxicol. 2001, 15, 171-187. [CrossRef]

65. Mendoza-Villarroel, R.E.; Robert, N.M.; Martin, L.J.; Brousseau, C.; Tremblay, J.J. The nuclear receptor NR2F2 activates Star expression and steroidogenesis in mouse MA-10 and MLTC-1 Leydig cells. Biol. Reprod. 2014, 91, 26. [CrossRef]

66. Martin, L.J.; Bergeron, F.; Viger, R.S.; Tremblay, J.J. Functional cooperation between GATA factors and cJUN on the star promoter in MA-10 Leydig cells. J. Androl. 2012, 33, 81-87. [CrossRef]

67. Martin, L.J.; Tremblay, J.J. The nuclear receptors NUR77 and SF1 play additive roles with c-JUN through distinct elements on the mouse Star promoter. J. Mol. Endocrinol. 2009, 42, 119-129. [CrossRef]

68. Manna, P.R.; Huhtaniemi, I.T.; Stocco, D.M. Mechanisms of protein kinase C signaling in the modulation of 3',5'-cyclic adenosine monophosphate-mediated steroidogenesis in mouse gonadal cells. Endocrinology 2009, 150, 3308-3317. [CrossRef]

69. Manna, P.R.; Stocco, D.M. Crosstalk of CREB and Fos/Jun on a single cis-element: Transcriptional repression of the steroidogenic acute regulatory protein gene. J. Mol. Endocrinol. 2007, 39, 261-277. [CrossRef]

70. Manna, P.R.; Eubank, D.W.; Stocco, D.M. Assessment of the role of activator protein-1 on transcription of the mouse steroidogenic acute regulatory protein gene. Mol. Endocrinol. 2004, 18, 558-573. [CrossRef]

71. Sugawara, T.; Saito, M.; Fujimoto, S. Sp1 and SF-1 interact and cooperate in the regulation of human steroidogenic acute regulatory protein gene expression. Endocrinology 2000, 141, 2895-2903. [CrossRef]

72. Silverman, E.; Eimerl, S.; Orly, J. CCAAT enhancer-binding protein beta and GATA-4 binding regions within the promoter of the steroidogenic acute regulatory protein (StAR) gene are required for transcription in rat ovarian cells. J. Biol. Chem. 1999, 274, 17987-17996. [CrossRef]

73. Christenson, L.K.; Johnson, P.F.; McAllister, J.M.; Strauss, J.F., III. CCAAT/enhancer-binding proteins regulate expression of the human steroidogenic acute regulatory protein (StAR) gene. J. Biol. Chem. 1999, 274, 26591-26598. [CrossRef]

74. Hu, Y.; Dong, C.; Chen, M.; Chen, Y.; Gu, A.; Xia, Y.; Sun, H.; Li, Z.; Wang, Y. Effects of monobutyl phthalate on steroidogenesis through steroidogenic acute regulatory protein regulated by transcription factors in mouse Leydig tumor cells. J. Endocrinol. Invest. 2015, 38, 875-884. [CrossRef]

75. Scott, H.M.; Mason, J.I.; Sharpe, R.M. Steroidogenesis in the fetal testis and its susceptibility to disruption by exogenous compounds. Endocr. Rev. 2009, 30, 883-925. [CrossRef]

76. Payne, A.H. Steroidogenic Enzymes in Leydig Cells. In The Leydig Cell in Health and Disease, 2nd ed.; Payne, A., Hardy, M.P., Eds.; Humana Press: Totowa, NJ, USA, 2007; pp. 157-171.

77. Slone, J.D.; Yang, L.; Peng, Y.; Queme, L.F.; Harris, B.; Rizzo, S.J.S.; Green, T.; Ryan, J.L.; Jankowski, M.P.; Reinholdt, L.G.; et al. Integrated analysis of the molecular pathogenesis of FDXR-associated disease. Cell Death Dis. 2020, 11, 423. [CrossRef]

78. Slone, J.; Peng, Y.; Chamberlin, A.; Harris, B.; Kaylor, J.; McDonald, M.T.; Lemmon, M.; El-Dairi, M.A.; Tchapyjnikov, D.; Gonzalez-Krellwitz, L.A.; et al. Biallelic mutations in FDXR cause neurodegeneration associated with inflammation. J. Hum. Genet. 2018, 63, 1211-1222. [CrossRef]

79. Peng, Y.; Shinde, D.N.; Valencia, C.A.; Mo, J.S.; Rosenfeld, J.; Truitt Cho, M.; Chamberlin, A.; Li, Z.; Liu, J.; Gui, B.; et al. Biallelic mutations in the ferredoxin reductase gene cause novel mitochondriopathy with optic atrophy. Hum. Mol. Genet. 2017, 26, 4937-4950. [CrossRef]

80. Boisvert, A.; Jones, S.; Issop, L.; Erythropel, H.C.; Papadopoulos, V.; Culty, M. In vitro functional screening as a means to identify new plasticizers devoid of reproductive toxicity. Environ. Res. 2016, 150, 496-512. [CrossRef]

81. Kermanshahi Pour, A.; Cooper, D.G.; Mamer, O.A.; Maric, M.; Nicell, J.A. Mechanisms of biodegradation of dibenzoate plasticizers. Chemosphere 2009, 77, 258-263. [CrossRef]

82. Kermanshahi Pour, A.; Mamer, O.A.; Cooper, D.G.; Maric, M.; Nicell, J.A. Metabolites from the biodegradation of 1,6-hexanediol dibenzoate, a potential green plasticizer, by Rhodococcus rhodochrous. J. Mass Spectrom 2009, 44, 662-671. [CrossRef] 
83. Kastner, J.; Cooper, D.G.; Maric, M.; Dodd, P.; Yargeau, V. Aqueous leaching of di-2-ethylhexyl phthalate and "green" plasticizers from poly(vinyl chloride). Sci. Total Environ. 2012, 432, 357-364. [CrossRef]

84. Albert, O.; Nardelli, T.C.; Lalancette, C.; Hales, B.F.; Robaire, B. Effects of In Utero and Lactational Exposure to New Generation Green Plasticizers on Adult Male Rats: A Comparative Study With Di(2-Ethylhexyl) Phthalate. Toxicol. Sci. 2018, 164, 129-141. [CrossRef]

85. Nardelli, T.C.; Albert, O.; Lalancette, C.; Culty, M.; Hales, B.F.; Robaire, B. In Utero and Lactational Exposure Study in Rats to Identify Replacements for Di(2-ethylhexyl) Phthalate. Sci. Rep. 2017, 7, 3862. [CrossRef]

86. Ascoli, M. Characterization of several clonal lines of cultured Leydig tumor cells: Gonadotropin receptors and steroidogenic responses. Endocrinology 1981, 108, 88-95. [CrossRef]

87. Martin, L.J.; Boucher, N.; El-Asmar, B.; Tremblay, J.J. cAMP-induced expression of the orphan nuclear receptor Nur77 in testicular Leydig cells involves a CaMKI pathway. J. Androl. 2009, 30, 134-145. [CrossRef]

88. Abdou, H.S.; Villeneuve, G.; Tremblay, J.J. The calcium signaling pathway regulates leydig cell steroidogenesis through a transcriptional cascade involving the nuclear receptor NR4A1 and the steroidogenic acute regulatory protein. Endocrinology 2013, 154, 511-520. [CrossRef]

89. Abdou, H.S.; Bergeron, F.; Tremblay, J.J. A cell-autonomous molecular cascade initiated by AMP-activated protein kinase represses steroidogenesis. Mol. Cell Biol. 2014, 34, 4257-4271. [CrossRef]

90. Enangue Njembele, A.N.; Bailey, J.L.; Tremblay, J.J. In vitro exposure of Leydig cells to an environmentally relevant mixture of organochlorines represses early steps of steroidogenesis. Biol. Reprod. 2014, 90, 118. [CrossRef] 